\title{
Enzymatic Bioelectrocatalysis
}

\section{Lojou, Elisabeth; Xiao, Xinxin}

\section{Published in:}

Catalysts

Link to article, DOI:

10.3390/catal11111373

Publication date:

2021

\section{Document Version}

Publisher's PDF, also known as Version of record

Link back to DTU Orbit

\section{Citation (APA):}

Lojou, E., \& Xiao, X. (2021). Enzymatic Bioelectrocatalysis. Catalysts, 11(11), [1373].

https://doi.org/10.3390/catal11111373

\section{General rights}

Copyright and moral rights for the publications made accessible in the public portal are retained by the authors and/or other copyright owners and it is a condition of accessing publications that users recognise and abide by the legal requirements associated with these rights.

- Users may download and print one copy of any publication from the public portal for the purpose of private study or research.

- You may not further distribute the material or use it for any profit-making activity or commercial gain

- You may freely distribute the URL identifying the publication in the public portal

If you believe that this document breaches copyright please contact us providing details, and we will remove access to the work immediately and investigate your claim 
Editorial

\title{
Enzymatic Bioelectrocatalysis
}

\author{
Elisabeth Lojou ${ }^{1, *(1)}$ and Xinxin Xiao ${ }^{2, *(1)}$ \\ 1 National Center for Scientific Research (CNRS), Aix Marseille University, BIP, UMR 7281, 31 Chemin Aiguier, \\ 13009 Marseille, France \\ 2 Department of Chemistry, Technical University of Denmark, 2800 Lyngby, Denmark \\ * Correspondence: lojou@imm.cnrs.fr (E.L.); xixiao@kemi.dtu.dk (X.X.)
}

Citation: Lojou, E.; Xiao, X. Enzymatic Bioelectrocatalysis. Catalysts 2021, 11, 1373. https:// doi.org/10.3390/catal11111373

Received: 9 November 2021 Accepted: 12 November 2021 Published: 14 November 2021

Publisher's Note: MDPI stays neutral with regard to jurisdictional claims in published maps and institutional affiliations.

Copyright: (c) 2021 by the authors. Licensee MDPI, Basel, Switzerland. This article is an open access article distributed under the terms and conditions of the Creative Commons Attribution (CC BY) license (https:// creativecommons.org/licenses/by/ $4.0 /)$.
Enzymatic bioelectrocatalysis relies on immobilizing oxidoreductases on electrode surfaces, leading to different applications, such as biosensors [1], biofuel cells [2], and bioelectrosynthesis [3]. Based on their intrinsic properties, i.e., high specificity and high affinity for the substrate, enzymes may provide sustainable alternatives to currently used chemical catalysts for human health monitoring, biopower generation or high-value product synthesis. However, enzyme bioelectrocatalysis suffers from low catalytic efficiency, imposing fundamental investigations on mechanisms of enzyme immobilization, including molecular basis knowledge of the efficient electronic communication between enzymes and the electrode. Bioelectrocatalysis is also limited by long-term stability requiring groundbreaking strategies for enzyme protection and bioelectrode survival.

The "Enzymatic Bioelectrocatalysis" Special Issue comprises six reviews contributed by research groups from different countries, covering fundamentals and applications, as well as the recent research progress in this field.

Enzyme immobilization and electron transfer mechanisms are two crucial and closely interrelated aspects, which ultimately determine the stability and efficiency of the bioelectrode. On the basis of understanding the parameters governing protein stability, Beaufils et al. discuss the major strategies to improve redox enzyme stability, with a focus on the immobilization as an important route [4]. The authors further discuss additional factors specific for bioelectrocatalysis, such as enzyme reorientation, effect of the electric field and protection against reactive oxygen species (ROS) production, that should be considered to achieve highly stable bioelectrodes undergoing electron transfer. For future directions, they emphasize the need to screen the diversity for the discovering of new outstanding enzymes with enhanced stability, as well as the requirement of in situ and in operando methodologies to get new insights on enzyme behavior in the immobilized state.

Gold and carbon electrodes represent two key materials for enzyme immobilization, which are respectively reviewed by Xia et al. [5] and Yan et al. [6]. Strategies used to rationalize surface modification for high-performance direct electron transfer (DET) of redox enzymes are especially discussed. Yan et al. emphasizes the employment of self-assembled monolayers (SAM) as tunable bridges between redox enzymes and gold electrode surfaces permitting DET [6]. The authors overview the characterization methods of SAMs and structural properties of common enzymes, highlighting the strategic selection of a specific SAM to control proper enzyme orientation. Xia et al. highlight the key parameters allowing enzymatic DET on carbon nanomaterials, and review the various methods for the oriented immobilization. Interestingly, they also present the tools currently developed to probe redox enzymes [5].

Membrane proteins, constituting 20-30\% of all proteins secreted by living organisms, are a major subject of bioelectrocatalysis. In the review by Zhang et al., various and eventually coupled techniques, i.e., electrochemistry, spectroscopy, microscopy, and quartz crystal microbalance [7] are discussed toward the understanding and use of membrane enzymes active in bioenergy conversion. Electrode designs with a special focus on the specificity required for membrane proteins are highlighted. Two emerging directions: (i) the membrane protein based 
hybrid vesicles for improved lifetime and (ii) microorganisms for microbial electrosynthesis and semi-artificial photosynthesis, are emphasized for future research.

Regarding to the applications of enzymatic bioelectrocatalysis, Adachi et al. describe the recent progress in emerging bioelectrochemical fields such as biosupercapacitor, bioelectrosynthesis and photo-bioelectrocatalysis [8]. The authors claim how crucial further research on protein-engineering, rational selection of electrode materials and mediators, immobilization of enzymes, and layout of electrodes to improve bioelectrocatalysis will be. The review by Arshi et al. focuses on the development of electrochemically based enzymatic reactors [9]. Together with the discussion on the mechanisms of electron transfer involving immobilized enzyme, the authors review the usage of electrochemically based batch and flow bio-reactors. They highlight the importance of high surface area electrodes, enzyme engineering and enzyme cascades, joining the general opinion formulated in the review by Adachi et al. [8]. Finally, both reviews provide some examples of enzyme-based electrosynthesis especially relevant in a sustainable world.

The common message conveyed from all the contributions of this special issue is that enzymatic electrochemistry is expected to play an increasingly role towards electrocatalysis in mild conditions. We look forward to further new developments in this exciting field.

Conflicts of Interest: The authors declare no conflict of interest.

\section{References}

1. Schachinger, F.; Chang, H.; Scheiblbrandner, S.; Ludwig, R. Amperometric Biosensors Based on Direct Electron Transfer Enzymes. Molecules 2021, 26, 4525. [CrossRef] [PubMed]

2. Xiao, X.; Xia, H.-q.; Wu, R.; Bai, L.; Yan, L.; Magner, E.; Cosnier, S.; Lojou, E.; Zhu, Z.; Liu, A. Tackling the Challenges of Enzymatic (Bio)Fuel Cells. Chem. Rev. 2019, 119, 9509-9558. [CrossRef] [PubMed]

3. Chen, H.; Simoska, O.; Lim, K.; Grattieri, M.; Yuan, M.; Dong, F.; Lee, Y.S.; Beaver, K.; Weliwatte, S.; Gaffney, E.M.; et al. Fundamentals, Applications, and Future Directions of Bioelectrocatalysis. Chem. Rev. 2020, 120, 12903-12993. [CrossRef] [PubMed]

4. Beaufils, C.; Man, H.-M.; de Poulpiquet, A.; Mazurenko, I.; Lojou, E. From Enzyme Stability to Enzymatic Bioelectrode Stabilization Processes. Catalysts 2021, 11, 497. [CrossRef]

5. Xia, H.; Zeng, J. Rational Surface Modification of Carbon Nanomaterials for Improved Direct Electron Transfer-Type Bioelectrocatalysis of Redox Enzymes. Catalysts 2020, 10, 1447. [CrossRef]

6. Yan, X.; Tang, J.; Tanner, D.; Ulstrup, J.; Xiao, X. Direct Electrochemical Enzyme Electron Transfer on Electrodes Modified by Self-Assembled Molecular Monolayers. Catalysts 2020, 10, 1458. [CrossRef]

7. Zhang, H.; Catania, R.; Jeuken, L.J.C. Membrane Protein Modified Electrodes in Bioelectrocatalysis. Catalysts 2020, $10,1427$. [CrossRef]

8. Adachi, T.; Kitazumi, Y.; Shirai, O.; Kano, K. Recent Progress in Applications of Enzymatic Bioelectrocatalysis. Catalysts 2020, 10, 1413. [CrossRef]

9. Arshi, S.; Nozari-Asbemarz, M.; Magner, E. Enzymatic Bioreactors: An Electrochemical Perspective. Catalysts 2020, $10,1232$. [CrossRef] 